\title{
RELIGIOUS TOURISM - FROM A TOURISM PRODUCT TO AN AGENT OF SOCIETAL TRANSFORMATION
}

\author{
Renata Tomljenović1, \\ Larisa Dukić ${ }^{1}$
}

${ }^{1}$ Institute for Tourism,

Zagreb, Croatia
Correspondence:

Renata Tomljenović

e-mail:

renata.tomljenovic@iztzg.hr

\begin{abstract}
:
The aim of this paper is to critically analyze the current scholarly and professional treatment of religious tourism that will amply illustrate the effect of the marketprofit driven paradigm on product and attraction development before proposing the fresh few on religious tourism as a potential agent of individual and collective transformation of values. This paper is a result of a broader research on the project „Trans-Tourism - An integrated approach for the study of transformative role of tourism in the 21st century" "which aims to critically investigate the role of tourism in attaining the vision for sustainable world of peace and harmony and to develop tools and options in order to provide policy proposals and practical models to harness the transformative power of tourism. The results indicate that religious / spiritual tourism really can foster both personal and societal transformation, mainly through the emphasis on the spirituality, or through providing experiences that make tourists reflect on their lives and their worldviews. In order to fully uphold this potential, we must step outside the mindset of religious tourism as a growing niche of tourism into the mindset of religious tourism as a transformation force that can facilitate personal and social change. Implications for further research are also presented.
\end{abstract}

Keywords:

religious tourism, spirituality, transformation, transformational tourism.

\section{INTRODUCTION}

Religious tourism (often also referred to as spiritual and faith tourism) is one of the fastest growing types of tourism in the world. The UNWTO estimates that 300-330 million tourists visit the world's major religious sites each year, which approximately 600 million national and international religious journeys are added to. Religious tourism includes a range of activities, such as pilgrimages, missionary travel, monastery / abbey retreats, faith-based camps / events, religious conferences and gatherings (CBI, 2016, December). Religious tourists travel in order to meet both their religious and spiritual needs.

Closely related to religious tourism is spiritual tourism that can be, but not necessarily, a part of religious tourism. Spiritual tourism is defined as

1 This project has been fully supported by the Croatian Science Foundation, under the project no. 6164 . 
"secular travel which purposely or inadvertently includes an experience, beyond the norm for the individual traveler, which impacts that individual's belief system"(Chesworth in Rogers, 2007). Therefore, we can define a spiritual tourist as someone who travels outside the place of his / her permanent residence in order to achieve spiritual growth (which can be religious, nonreligious, sacred or experiential in nature) (Haq \& Jackson in Rogers, 2007). In a survey released in November 2006, the Travel Industry Association found that a quarter of all respondents in a representative sample of 1500 adults said they were interested in spiritual vacations (The Sacred Journey, 2017).

These numbers are likely to be higher today, as the absolute number of both believers in God and secularists is increasing. However, data available from Eurobarometer Pool 2015 imply a division between secularism and religiosity of the European world. However, the number of believers in God increases mainly because of the general population growth, but the increase of secularists implies that Europeans are increasingly drifting from traditional religions toward more spiritual ways of practicing their faith. Also, the number of people who don't consider themselves religious, but are interested in spirituality is increasing. All this data implies that the market for religious/spiritual tourism is big and continues to grow. The available literature from, both, professional and academic sources, tends to treat religious tourism as a product. Thus religiosity as well as religious travel is moved away from the realm of spiritual enrichment/well-being and turned into yet another commodity to be sold. The aim of this paper is to critically analyze the current scholarly and professional treatment of religious tourism that will amply illustrate the effect of the market-profit driven paradigm on product and attraction development before proposing the fresh few on religious tourism as a potential agent of individual and collective transformation of values. This transformation, as is further argued, is urgently needed if we are to sustain our civilization into the next century.

\section{RELIGION AND RELIGIOUS TOURISM AS A PRODUCT}

An extended body of contemporary research uses the approach to religion as a product (Cunningham, 2000; Einstein, 2008; Kosmin\&Keysar, 2006; Kuzma, Kuzma\&Kuzma, 2009). Religion has become only one of many products offered and sold in the global "marketplace of ideas" (Kosmin\&Keysar, 2006). In order to be consumed /bought, it needs to compete with other religions, but also with a number of other more convenient and entertaining leisure activities (Einstein, 2008). Though packaged differently, the majority of religions offer the same end benefit for the consumer self-exploration, meaning and purpose, forgiveness and salvation, peace of mind, and similar. The only way to differentiate one religion from another is through services provided and the symbols that designate it (Cunningham, 2000). When approached in this way, it is tempting to see religion as a product, with branding as a key marketing technique used to compete for customers (Cunningham, 2000). Religious institutions need to craft sales messages and keep up with the changes on the religion market. Einstein (2008) explains this phenomenon by pointing out the two main reasons why religious marketing appeared and continues to operate in America. First, millions of people have been set free to choose their religion. It is precisely this ability to choose that created the real open market for religion. Second, the level of media saturation expanded beyond every imaginable boundary. Simply put - more media means more religious media. This results with the competition for new religious consumers between different religions, but also with religions presented in other forms. The ability to choose religion further introduced change of the concept of spirituality in post-modern society; there is a noted decline of allegiance to religious doctrine and an evident movement toward self-development and interconnectedness with the Earth. Many people create their own highly individualized religious practices by choosing and accepting traditions and beliefs from a variety of religions (Kuzma et al., 2009). Religion no longer represents an inherited tradition. Instead, many young people choose for themselves. It is estimated that 1,000 people a day find a new religion (Cunningham, 2000).

The approach to religion as a product is also reflected in the contemporary research on religious tourism where the narratives of products and marketing are predominant. A large body of current research focuses on practical issues of motivation (Cohen, 2003; CollinsKreiner, 2004; Nieminen, 2012), satisfaction (Canoves\& Prat Forga, 2016; Krešić, Mikulić\&Miličević, 2012), religious tourist experiences (Bond, Packer \& Ballantyne, 2014; Hughes, Bond \& Ballantyne, 2013) and decision making models in religious travel (Henderson, 2010; Kunst, Tomljenović, Kranjčević, Krešić\&Miličević, 2009; The Churches Conservation Trust and The Churches Tourism Association, 2006). This touristconsumer / demand-side approach to religious tourism studies is a direct consequence of treating tourism as an industry, and results in the lack of insight into the process of personal change undergone by tourist. 
Treating tourism as an industry implies nurturing isolationist approach based on rationality and positivism. In this way, transformation engaging with emotions, hopes and feelings becomes devalued, as they fall outside market parameters. More recently, however, a number of scholars reinvigorated the interest in the theme of tourism as a social force by the post 9/11 security and political challenges, economic and financial collapses and threats posed by climate change. The impetus also came from the recent "critical turn" in tourism studies (Ateljevic, Pritchard \& Morgan, 2007; 2012) as a growing number of tourism scholars has got engaged with the critical theory. There is an increasing trend of the growing need for transformative holidays in which travel provides the means of changing one's own lifestyle and the impact one makes on places of visit. Although different authors from different discipline use a variety of terms, such as trans-modern tourism of the future (Ateljević, 2009; 2011), transformative tourism from the tourist and host perspective (Reisinger, 2013; 2015), transformative travel and sustainability ambassadors (Lean, 2009) or conscious travel (Pollock, 2015), they all point to the same direction - there is a need for a shift towards a new travelling mind set. These transformative travelers use travel to reflect upon their lives and gain courage to make crucial life changes upon their return back home. They value what's slow, small and simple and aim for self-reliance; they are connected and communicative; they seek meaningful experiences that help them to develop personally and collectively (Ateljević\&Tomljenović, 2016).

\section{CALL FOR A PARADIGM SHIFT}

This need for a shift towards a new travelling mindset is only a part of the major call for the global mind change and the paradigm shift in the 21 st century. An increasing number of professionals all over the world are starting to question the long-term viability of today's dominant economy model and envision a new one (Tomljenović\&Ateljević, 2017). This is greatly illustrated by Atkisson (2006): “At the dawn of the Third Millennium, human civilization finds itself in a seeming paradox of gargantuan proportions. On the one hand, industrial and technological growth is destroying much of Nature, endangering ourselves, and threatening our descendants. On the other hand, we must accelerate our industrial and technological development, or the forces we have already unleashed will wreak even greater havoc on the world for generations to come. We cannot go on, and we cannot stop. We must transform". The call for paradigm shift from rational / positivistic world view of economic efficiency to the trans-modern paradigm based on the new mindset has been made. The new mind set will be built upon:

- planetary citizenship of interdependence and biosphere politics,

- partnership model of caring economics,

- egalitarian and respectful vision for all living beings,

- spiritual (non-religious), circular and hopeful values (Ateljević 2009; 2011).

It is assumed that the transformation will be driven by the "cultural creatives" through the so-called "silent revolution". The concept of the silent revolution of cultural creatives comes from the historian Arnold Toynbee who analyzed the rise and fall of 23 civilizations in the world history and who claims that when a cultural shift occurs, usually $5 \%$ of "creative marginal" are preparing the shift in silence (Ghisi in Ateljević\&Tomljenović, 2016).

The term "cultural creatives" was coined by sociologist Paul H. Ray and psychologist Sherry Ruth Anderson to describe a large segment in Western society that has developed beyond the standard paradigm of Modernists versus Conservatives. They constitute a $1 / 4$ th of developed world's population and share and nurture transmodern values that (will) change patterns of consumption:

- Ecological sustainability,

- Positive social values (empathy, quality social contact in private and public life),

- Altruism (personal growth, self-realization and spirituality),

- Authenticity (behavior in tune with values and beliefs),

- Social activism (for building sustainable future).

They reflect on themselves, actively travel and are looking for a spiritual dimension in life that goes beyond religious dogmas. In everyday life they search for the harmony of the body, mind and spirit; hence their travels often consist of spiritual and educational trips (e.g. retreats and events focused on spirituality and inner search, well-being, alternative medicine) (Ray \& Anderson, 2000).

\section{THEORETICAL FRAMEWORK ON TRANSFORMATION}

According to Mezirow (1996; 2012), there are several levels of transformation:

- psychological - relating to deeper understanding of self, 
- convictional - relating to beliefs and entire ideologies,

- behavioral - occurs when specific behaviors and lifestyles of persons, their families, communities and entire societies change.

Similarly, O'Sullivan (2012) argues that the transformation to foster planetary world-view encompasses education for survival (learning how to ensure the condition for living to continue), critical understanding (understanding the factors and conditions that brought us to this devastating historical model) and integral creativity (challenging hegemonic culture or the market driven vision and orient people to create environmentally viable ways of living). According to Tisdell (2012), societal transformation challenges power relations based on gender, race, class, religion or sexual orientation and this body of work takes transformative to mean - teaching to challenge power relations.

Paths to transformation can be intentional or accidental. An intentional path to transformation implies that one has to conscientiously decide to embark on travel that will be challenging and, potentially, transformational (Ross, 2010). An accidental path to transformation usually involves some kind of unexpected challenge faced by travelers in new or unfamiliar environments through a culture shock (as proposed in sojourn studies/cross-cultural adaptation studies (Lyon, 2002), culture confusion (as proposed by Hottola (2004) based on studies of backpackers in India and Sri Lanka) or a disorienting dilemma (as proposed in transformational learning theory (Taylor, 2007)). When the existing values, norms and learned behavioral response do not function, one becomes confused and disoriented until he/she adapts and this adaptation usually involves deep transformational change. Transformation can be triggered by independent travel (Hottola, 2014), the new environment in significant contrast with the home or ordinary surroundings (Reisinger, 2013a; 2013b), or activities stimulating contemplation and self-reflection (Lean in Ross, 2010).

At the outset we have argued that the prevailing market approach to religious tourism is a reflection of a dominant, but highly unsustainable, market-driven paradigm and a view of tourism as an industry with a main aim to generate profit. Furthermore, as amply illustrated, at the time when we need to be concerned with the survival on our plane and when the limits to the neo-liberal growth model are becoming clearly visible, the power of tourism in general, and spiritual/religious tourism in particular in fostering the individual and societal change has been neglected. In this context, the aim of the study reported here is to investigate in what ways religious / spiritual tourism can foster transformation and change.

\section{METHODOLOGY}

The research on religious/spiritual tourism as an agent of societal transformation is part of a broader research on the project „TRANS-TOURISM - An integrated approach for the study of transformative role of tourism in the 21st century", funded by the Croatian Science Foundation (Project No. 6164). Therefore, a part of the used methodological and theoretical framework relevant for this paper has already been partially used and presented in previous papers that resulted from work on the TRANS-TOURISM project (Tomljenović\&Ateljević, 2015a; Tomljenović\&Ateljević, 2017). The overall objective of TRANS-TOURISM is to critically investigate the role of tourism in attaining vision for sustainable world of peace and harmony and to develop tools and options in order to provide policy proposals and practical models to harness the transformative power of tourism. One of the main TRANS-TOURISM project objectives is researching motivations and practices of pioneering change-makers who create transformational travel products and tourism stakeholders' receptiveness to integrate transformational view of tourism into design of their products. Methodological framework, in this respect, consisted of web-based mapping of the transformative tourism providers in four countries included in this project - Croatia, Hungary, Germany and United Kingdom and, afterwards, conducting in-depth interviews with twelve chosen transformative tourism providers - four in Germany, three in the UK, three in Croatia and two in Hungary. Web-based mapping was based on keyword research for each type of potentially transformative tourism experience. Keywords used for web-mapping of religious tourism were: yoga, meditation, spiritual, religious, monastic, Christian, abbey and monastery retreat/holidays, retreat for pilgrims - which were chosen after a preliminary web-mapping and literature review. The research was undertaken in the period from 12th January to 10th June 2015. The literature review on religion and religious tourism provided basis for a critical analysis of the current scholarly and professional treatment of religious tourism primarily as a product, and not as a force that can potentially lead to societal transformation. 


\section{RESULTS AND DISCUSSION}

If we understand religion as a way of strengthening spiritual sense of self, and spirituality as a "very individual quest to find meaning in the broader scheme of things" (Rifkin, 2010), we can conclude that the transformative potential of religious / spiritual tourism mainly relates to the motivation of tourists to search for a deeper understanding of the self and the meaning of life. Travel can indeed, through the offer of experiences aimed at the spiritual dimension, encourage spiritual awakening that leads to seeing the world anew. By using this as a starting point for our research, webbased mapping aimed to identify those transformative providers of religious / spiritual tourism that focus their offer on the spiritual dimension was conducted. Webbased mapping resulted in the creation of a data-base of transformative tourism providers in Croatia, Germany, Hungary and United Kingdom available online: http:// www.transtourism.com/hr/aktivnosti/post.php?s=database-of-travel-providers-on-the-projects-web-site. In terms of spiritual / religious tourism, we identified activities and experiences offered in spiritual and religious centers, monasteries and retreat centers. Programs offered in the identified spiritual and religious centers or monasteries offer a range of activities such as praying, liturgy, spiritual conversations, creative workshops (like painting or dancing), contemplation, meditation and spiritual practices. Retreat centers aiming to practice a more holistic approach to personal development offer a combination of wellness and spirituality, with activities including yoga, meditation, nature-base activities and special diets (Tomljenović, 2015). A great example of a transformative religious tourism provider is the Iona Community in United Kingdom that runs three island residential centers. The Iona Community consists of a number of people who strive to fully live their Christian faith. Their offer is shaped around a variety of themes, such as faith and spirituality, social justice, human rights and peacemaking. Some of the activities tourists can participate in are praying, pilgrimages, trips around the island, creative workshops and regular sessions. An example of a monastery offering transformational experiences can be found in Germany, in a Benedictine monastery Frauenwörth run by nuns. Visitor accommodation is offered in form of rooms in the monastery. The main activities offered are: meditation, prayer, liturgy, coexistence with nuns, spiritual conversations, painting, dancing and music. They are aimed at guests seeking peace, refuge and contemplation. An example of a monastery open to all types of spirituality is the Pauline - Carmelite Monastery of Sopronbánfalva in Hungary.
Itis a non-profit meditation and educational center and retreat that offers a range of activities, such as yoga, meditation, prayer, spiritual exercises. It offers programs for individuals, groups and companies who wish to experience a spiritual transformation (The Pauline - Carmelite Monastery of Sopronbánfalva, 2017). The retreats are often settled in isolated, peaceful areas, such as the one on the island of Vis in Croatia (Summersalt Yoga, 2017). They are primarily focused on the philosophy and lifestyle of yoga and peace and wish to gather likeminded people that will (continue to) live in a socially, economically and environmentally responsible way and contribute to the society both globally and locally. As can be seen from these examples, identified transformative tourism providers in religious / spiritual tourism in Croatia, Hungary, Germany and United Kingdom create experiences that stimulate rethinking the self and the meaning of life that can potentially trigger both personal and societal transformation. The creation of these types of transformative religious/spiritual tourism experiences is strongly connected to the beliefs and values of a person standing behind them. As Ana Božac, artist and psychotherapist located in Istria points out: "I believe in holistic approach through integration of Eastern spirituality and Western knowledge, psychology, creativity and spirituality. I value greatly in return to nature (internally and externally) and tuning into the natural rhythm of oneself and nature" (Ana Božac, 2017). Overall results also point to the existence of certain differences in offer and features of the transformative religious/spiritual tourism experiences in four countries included in this study. In Croatia, these types of experiences are offered mostly in its coastal part, most often during the summer months. Some are run by foreign companies or nationals and some are offered by Croatian citizens. In Hungary, dedicated spiritual retreats are relatively rare (or don't aim at the international market), although there are some experiences offered as a special weekend and/ or week retreats led by reputed teachers and organized mostly in wellness/health hotels or similar accommodation facilities. In Germany, there are many transformative tourism providers, although the majority of them aim at domestic markets. Only monasteries and some large organization such as yoga or alternative spiritual movements running their own facilities offering retreats aim for an international audience. In the United Kingdom, transformative experiences are offered by many monasteries/abbeys, spiritual movements and individual spiritual teachers (Tomljenović, 2015).

The results of our study are in accordance with the previous studies concerned with the role of religious / spiritual tourism as an agent of both personal and societal. 
Heintzmann (2013) concluded that retreats foster personal transformation by facilitating the restoration of mind and body, relaxation, positive outlook and clearheaded thinking, which leads to the acquisition of new skills, knowledge and/or training (i.e. meditation techniques), and finally results in improved self-identity. Through the development of altruism, compassion and a sense of justice, religious/spiritual tourism can potentially lead to community transformation and, in that way, contribute to a better world. Ross (2010) argues that all types of pilgrimage (historic or traditional, goddess pilgrimage, pilgrimage to sacred sites) are conductive to transformation as they provide opportunities for reverence, reflection, ritual ceremony and other non-ordinary states of consciousness that provoke the feeling of oneness and unity. Pilgrimage can be defined as a temporary replacement of profane with spiritual life where individuals intensively connect with other pilgrims (Smith, 2013). Intensive identification with other pilgrims, as well as with the religious or spiritual culture in general, strengthens feelings of connection with God and others, develops altruism, and promotes peace (Brunn, 2015; Heintzman, 2013; Jung Lee \&Gretzel, 2013: Ross, 2010). Apart from traditional religious pilgrimage, Ross (2010) also notes the importance of modern pilgrimage (i.e. new age / mystic pilgrimage) and other types of modern rites of passage not necessarily related to religion, as transformational since traveler seeks spiritual transformation through experiencing and learning new and different things. Such travel may include meditations, rituals, ceremonies, even consummation of hallucinogenic drugs, or visiting places that promote self-reflection and respect for all living beings. Many different types of tourism hold the transformative potential, religious / spiritual tourism being one of them (Reisinger, 2013). It is in the approach to tourism as a social force where the true force of religious tourism as an agent of societal transformation can be found. The project findings of the TRANS-TOURISM project in general indicate that tourism truly is a force through which people re-define themselves and the world in which they live, as they travel to fulfil their dreams, develop their potential and seek the meaning of life. The learning component of travel plays a crucial role in this process as tourists use it to learn new skills, gain knowledge on sustainability, deepen sense of self and engage in hobbies, have meaningful interactions with hosts and do good - volunteer.

\section{CONCLUSION}

This study examined the role of religious / spiritual tourism as an agent of societal transformation. The results indicate that religious / spiritual tourism really can foster both personal and societal transformation, mainly through the emphasis on the spirituality, or through providing experiences that make tourist reflect on their lives and their worldviews. In order to fully uphold this potential of religious/spiritual tourism, answers to two key questions need to be given:

- How to step outside the mindset of religious tourism as a growing niche of tourism into the mindset of religious tourism as a transformational force that can facilitate personal and social change?

- How to build these transformative practices into mainstream tourism products?

It is likely that such an approach would generate higher level of support of religious and spiritual service providers who are often resisting taking part in tourism and setting up facilities and services for large number of tourists. In this line of reasoning, there are many avenues for further research, from ascertaining attitudes of religious and spiritual leaders towards the idea of partaking in such wider social movements to investigating actual processes of transformation in such settings.

\section{REFERENCES}

Ateljevic, I. (2011). Transmodern Critical Tourism Studies: A call for hope and transformation. Revista Turismoem Analise special issue: Critical Issues in Tourism, 22(3), 497-515.

Ateljevic, I. (2009). Transmodernity - remaking our (tourism) world? In J. Tribe (Ed.), Philosophical Issues of Tourism (278-300). Bristol: Channel View Publications.

Ateljevic, I. Pritchard, A., \& Morgan, N. (2012). The Critical Turn in Tourism Studies: Promoting an Academy of Hope. Oxford: Routledge.

Ateljevic, I., Pritchard, A., \& Morgan, N. (2007). The Critical Turn in Tourism Studies: Innovative Research Methodologies. Oxford: Elsevier.

Ateljević, I., \& Tomljenović, R. (2016). Triple T: Tourism, transmodernity and transformative learning. Turističko poslovanje. 17, 25-33.

Atkisson, A. (2006). Sustainability is Long Dead - Long Live Sustainability. In M. Keiner (Ed.), The Future of Sustainability (231-243). New York: Springer. 
Bond, N., Packer, J., \& Ballantyne, R. (2014). Exploring Visitor Experiences, Activities and Benefits at Three Religious Tourism Sites. International Journal of Tourism Research. 17(5), 471-481.

Božac, A. (2017). Program zaosobni rast i razvoj kreativnih potencijala. Retrieved September 12, 2017, from http://www.anabozac.com/. In Croatian.

Brunn, S. D. (2015). The Changing World Religion Map: Sacred Places, Identities and Politics. Berlin: Springer.

Canoves, G., \& Prat Forga, J. M. (2016). The Determinants of Tourist Satisfaction in Religious Destinations: the case of Montserrat (Spain). International Journal of Religious Tourism and Pilgrimage. 4 (5), 26-36.

CBI (2016, December). What are the opportunities for Religious Tourism from Europe? Retrieved September 9, 2017, from: https://www.cbi.eu/market- information/tourism/religious-tourism/.

Cohen, E.H. (2003). Tourism and religion: A case study - Visiting Students in Israeli Universities. Journal of Travel Research. 42(1), 36-47.

Collins-Kreiner N. (2004). Jewish Pilgrimage Tourism in Israel: Holy Tombs as Tourist Attractions. Horizons in Geography. 61(62), 267-278.

Einstein, M. (2008). Brands of Faith: Marketing Religion in a Commercial Age. New York: Routledge.

Heintzman, P. (2013). Retreat Tourism as a Form of Transformational Tourism. In Y. Reisinger (Ed.), Transformational tourism: tourist perspectives (6881). Wallingford: CABI.

Henderson, J. C. (2010). Religious Tourism and its management: the hajj in Saudi Arabia. International Journal of Tourism Research. 13(6), 541-552. DOI: $10.1002 /$ jtr.825

Hottola, P. (2014). Somewhat empty meeting ground. Travelers in South India. Annals of Tourism Research. 44(2014), 270-282.

Hottola, P. (2004). Culture confusion: Intercultural adaptation in tourism. Annals of Tourism Research. 31(2), 447-466.

Hughes, K., Bond, N., \& Ballantyne, R. (2013). Designing and managing interpretive experiences at religious sites: Visitors' perceptions of Canterbury Cathedral. Tourism Management. 36, 210-220.

Iona Community (2017). Iona Community: About Us. Retrieved September 12, 2017, from: https://iona. org.uk/about-us/.

Jung Lee, Y., \& Gretzel, U. (2013). Nearer to God Transformational Experiences of Short-term Mission Travelers. In Y. Reisinger (Ed.), Transformational tourism: tourist perspectives (82-97). Wallingford: CABI.

Kosmin, B. A., \& Keysar, A. (2006). Religion in a Free Market: Religious and Non-religious Americans: Who, What, Why, Where. New York: Paramount Market Publishing.
Krešić, D., Mikulić, J., \& Miličević, K. (2012). The Factor Structure of Tourist Satisfaction at Pilgrimage Destination: the Case of Medjugorje. International Journal of Tourism Research. DOI: 10.1002/ jtr.1891.

Kunst, I., Tomljenović, R., Kranjčević, J., Krešić, D., \& Miličević, K. (2009). Projekt Badija - Koncept najbolje uporabe otoka. Zagreb: Institut za turizam.

Kuzma, A., Kuzma, A., \& Kuzma, J. (2009). How Religion has Embraced Marketing and the Implications for Business. Journal of Management \& Marketing Research. 2 (1), 1-10.

Lean, G.L. (2009). Transformational travel - inspiring sustainability. In R. Bushel \& P. Sheldon (Ed.), Wellness and Tourism: Mind, Body, Spirit, Place. New York: Cognizant.

Lyon, C. R. (2002). Trigger Event Meets Culture Shock: Linking the Literature of Transformative Learning Theory and CrossCultural Adaptation. In Annual Meeting of the Adult Education Research Conference, May 24-26. Raleigh: North Carolina State University.

Mezirow, J. (2012). Learning to think like an adult: Core concepts of transformational learning theory. In E. W. Taylor, P. Cranton and Associates (Ed.), The Handbook of Transformative Learning: Theory, Research, and Practice. 73-95. San Francisco: John Wiley and Sons.

Mezirow, J. (1996). Contemporary paradigms of learning. Adult Education Quarterly. 46, 158-172.

Nieminen, K. (2012). Religious Tourism - A Finnish Perspective. Master Thesis in Hospitality Management. Helsinki: HAAGA-HELIA, University of Applied Sciences.

O'Sullivan, E. (2012). Deep transformations: Forging a planetary worldview. In E.W. Taylor, P. Cranton and Associates (Ed.), The Handbook of Transformative Learning: Theory, Research, and Practice.162-177. San Francisco: John Wiley and Sons.

Pollock, A. (2015) Social Entrepreneurship in Tourism: The Conscious Travel Approach. Tourism Innovation Partnership for Social Entrepreneurship (TIPSE): UK.

Reisinger, Y. (2015). Transformational tourism: host perspectives. Oxfordshire: CABI.

Reisinger, Y. (2013). Connection between travel, tourism and transformation. In Y. Reisinger (Ed.), Transformational tourism: tourist perspectives. 27-31. Oxfordshire: CABI.

Rogers, C.J. (2007). Secular spiritual tourism. Retrieved September 12, 2017, from: http://www.iipt.org/africa2007/PDFs/CatherineJRogers.pdf.

Ross, S. L. (2010). Transformative travel: An enjoyable way to foster radical change. ReVision. 32(1), 54-61. 
Smith, M. (2013). Transforming Quality of Life through Wellness Tourism. In Y. Reisinger (Ed.), Transformative tourism: tourist perspectives. 55-67. Wallingford: $\mathrm{CABI}$.

Summersalt Yoga (2017). Yoga Retreats. Retrieved September 12, 2017, from http://summersaltyoga. $\mathrm{com} /$.

Taylor, E. (2007). An update on transformational learning theory: a critical review of the empirical research (1999-2005). International Journal of Lifelong Education. 26(2), 173-191.

The Churches Conservation Trust and The Churches Tourism Association (2006). Sacred Britain. London: Sacred Britain Working Group.

The Pauline - Carmelite Monastery of Sopronbánfalva (2017). Retreat. Retrieved September 12, 2017,from http://www.banfalvakolostor.hu/en/calm- retreat/.

The Sacred Journey (2017). Sacred Journey. Retrieved September 9, 2017, from: https://sacredjourney. com/.
Tisdell, E. J. (2012). Themes and variations in transformational learning: Interdisciplinary perspective on forms that transform. In E.W. Taylor, P. Cranton and Associates (Ed.), The Handbook of Transformative Learning: Theory, Research, and Practice, 2136. San Francisco: John Wiley and Sons.

Tomljenović, R. (2015). Main features of transformative travel enterprises. Working paper No 4. Zagreb: Institute for Tourism.

Tomljenović, R., \& Ateljević, I. (2017). Transformative tourism, social entrepreneurs and regenerative economy. In Conference proceedings 6th International Scientific Symposium Economy of Eastern Croatia - Vision and growth, 2-4 June, 577-586. Osijek: Sveučilište Josipa Jurja Strossmayera u Osijeku, Ekonomskifakultet.

Tomljenović, R. , \& Ateljević, I. (2015a). Transtourism - theoretical and methodological foundations. Working paper No 1. Zagreb: Institute for Tourism.

UNWTO (2011). Religious Tourism in Asia and the Pacific. Madrid: UNWTO. 